\title{
DISTRIBUTION OF WESTERN (GLASSHOUSE STRAIN) AND INTONSA FLOWER THRIPS IN NEW ZEALAND
}

\author{
D.A.J. TEULON and M-C. NIELSEN \\ Crop \& Food Research, Private Bag 4704, Christchurch, New Zealand \\ Corresponding author: teulond@crop.cri.nz
}

\begin{abstract}
Western flower thrips (WFT) (Frankliniella occidentalis) ('glasshouse strain') and Intonsa flower thrips (IFT) (Frankliniella intonsa) are polyphagous pests that were first recorded in New Zealand in 1992 and 2002, respectively. Surveys were carried out to determine the distribution of these two insects, providing useful information for pest management, market access and biosecurity. Crops (mostly capsicum) were sampled for thrips in 18 greenhouses in the South Island in March/April 2004 and in16 greenhouses in the North Island in November/December 2004 and March 2005. Six outdoor crops (three in each island) were also sampled. Between 20 and 50 flower buds were sampled from each greenhouse and thrips were extracted, slide-mounted and identified to species. The results showed that WFT is widely distributed throughout New Zealand, while IFT is only recorded in samples from Auckland and Waikato.

Keywords: Frankliniella occidentalis, Frankliniella intonsa, New Zealand distribution.
\end{abstract}

\section{INTRODUCTION}

Thrips (Thysanoptera) are pests on a wide variety of ornamentals, fruits and vegetables where they cause damage as a result of direct feeding and through the transmission of viruses (Lewis 1997). Over 120 thrips species have been recorded in New Zealand with about half of these being introduced. Many of the introduced species, especially those belonging to the Thripidae, are pests (Mound \& Walker 1982, 1986). Thrips comprise a significant and ongoing biosecurity risk with many additional pest species that have the potential to invade New Zealand (Palmer et al. 1987; Kirk \& Terry 2003).

A pesticide-resistant 'glasshouse' strain of Western flower thrips (WFT) (Frankliniella occidentalis) was discovered in the Auckland region in 1992 infesting a greenhouse capsicum crop (Martin \& Workman 1994). A 'lupin' strain of this species had been recorded in New Zealand since 1934 (Mound \& Walker 1982). It is not resistant to insecticides (Martin \& Workman 1994) and is not considered to be a pest of crop plants (indoor or outdoor). The only effective way to distinguish between these two strains is by toxicological bioassays (Martin \& Workman 1994) or by molecular characterisation (P. Brunner \& J. Frey, pers. comm.). Martin \& Workman (1994) consider that the 'glasshouse' strain was a recent arrival adapted to spray regimes in greenhouses. It is likely that WFT found in covered crops in New Zealand are the 'glasshouse' strain. The Intonsa flower thrips (IFT) (Frankliniella intonsa) was first recorded in the Auckland region in 2002 (Gill 2002). Both these species are important pests on a number of different crops throughout the world and each has the ability to vector several debilitating plant viruses (Palmer et al. 1987).

The recent invasion and establishment of these two pest flower thrips in New Zealand has focused attention on this group. This paper describes surveys to determine the distribution of the 'glasshouse' strain of WFT and of IFT in New Zealand to enable informed pest management, facilitate market access for crops potentially infested by these species, and provide evidence for pathways of entry into, and spread within New Zealand. 


\section{METHODS}

The Plant Pest Information Network (PPIN), a New Zealand database, was interrogated for records of WFT and IFT in April 2005 and their distribution was characterised.

Two separate field surveys for WFT and IFT were undertaken, one in the South Island in March/April 2004 and the other in the North Island in November/December 2004 and March 2005. In both surveys it was attempted to take thrips samples from at least one site in each of the Crosby locations (Crosby et al. 1976) that separate the three main islands of New Zealand into 29 regions. The flowers of capsicum crops were targeted as these are known to harbour sizable populations of flower thrips. However, the flowers of other host plants (Palmer et al. 1989), such as chili, cucumber and flower crops, as well as the leaves of hydroponic lettuces were sampled when capsicums could not be found in the area. All crops were grown indoors (i.e. in glasshouses, greenhouses or tunnel houses) unless otherwise stated. Initially, samples were collected by growers and mailed to Crop $\&$ Food Research where they were examined for thrips. However, the size and quality of these samples varied greatly and so Crop \& Food Research staff collected subsequent samples. This included examining between 20 and 50 flowers (depending on greenhouse size) either by tapping the flowers over white plastic trays and collecting emerging thrips or by removing flowers from the plant into sealable plastic bags and examining them for thrips in the laboratory. All thrips were collected, slide-mounted and identified (only one tubuliferan specimen was present) using Mound \& Walker (1982).

\section{RESULTS}

There were four records of IFT in the PPIN database and about 18 for WFT. All IFT records were from Auckland in February and March 2002. Since 1992, when the 'glasshouse' strain was first reported in New Zealand, WFT has been recorded from three Crosby locations in the North Island (Auckland, Waikato and Bay of Plenty) and two in the South Island (North and Mid Canterbury). However, only three of these records distinguished between the 'lupin' strain and the 'glasshouse' strain and none indicated whether the record was from an indoor or outdoor crop. Thus, any interpretation of these data in relation to the distribution of the 'glasshouse' strain is problematic.

Largely as a result of not being able to find suitable sampling locations (i.e. indoor crops) samples were not taken in four Crosby locations in the North Island (Coromandel, Taupo, Rangitikei and Wairarapa) and four in the South Island (Marlborough Sounds, Buller, Westland and Fiordland). WFT was recorded in five Crosby locations (out of a total of 13) in the North Island. The locations were widespread including records from the north (Warkworth), east (Hastings), west (New Plymouth) and south (Manakau-Otaki) of the island (Table 1). Notably, WFT was not recorded in Northland, Bay of Plenty, Gisborne and Wanganui. In the South Island WFT was recorded in 10 Crosby locations out of a total of 16 including records from the north (Richmond), east (Kaikoura, Christchurch and Dunedin), west (Westport) and south (Edendale), although the records for two locations (South Canterbury and Mackenzie) were from outdoor roses (Table 1). Of the locations sampled, WFT was not found in Otago Lakes and Stewart Island (a small sample). IFT was only found in two Crosby locations in the North Island (Auckland and Waikato). It was not found in the South Island. Of the other thrips species recorded, New Zealand flower thrips (Thrips obscuratus) and especially onion thrips (Thrips tabaci) were the most common, with six other species being found in very small numbers (Table 1).

\section{DISCUSSION}

Between 1992 and 2005 the distribution of the WFT 'glasshouse' strain has expanded from Auckland to include many widely dispersed areas of New Zealand. With increased sampling effort, WFT would probably be found in all locations where its host plants are grown indoors. The WFT 'glasshouse' strain is now also considered to be infesting outdoor lettuces in large numbers in the Pukekohe district (P.J. Workman, unpubl. data).

It is reasonable to assume that indoor populations of WFT belong to the 'glasshouse' strain because the 'lupin' strain has not been recorded indoors (Mound \& Walker 1982; 
N.A. Martin pers. comm.). As the 'lupin' strain was recorded from several host plants including lupin (Mound \& Walker 1982) it is possible that WFT found in outdoor crops may be either strain. A molecular marker, such as that reported by P. Brunner \& J. Frey (pers. comm.), would be useful for identifying the strains of these thrips.

IFT has been recorded in New Zealand since 2002. This survey indicates that it has a relatively restricted distribution from around Auckland and parts of the Waikato. However, IFT is not primarily found in glasshouses so an outdoor survey is required to confirm its current distribution. IFT have been trapped in $7.5 \mathrm{~m}$ high suction traps in Pukekohe (South Auckland) but not in Ngatara (Hawke's Bay) or Lincoln (Canterbury) (M-C. Nielsen \& D.A.J. Teulon, unpublished data).

The cosmopolitan onion thrips is a pest of many crop plants (Mound \& Walker 1982). It was first reported in New Zealand in 1926 (Mound \& Walker 1982) and, as our survey showed, is distributed widely throughout the country. New Zealand flower thrips, an indigenous species found throughout the country, damages a number of crops (Teulon $\&$ Penman 1995). This species is of significant quarantine importance.

Kirk \& Terry (2003) speculate that the worldwide spread of the WFT 'glasshouse' strain was mainly the result of the movement of horticultural material as well as diffusion from source. Furthermore, resistant insect strains may be more likely to spread and establish than non-resistant strains because they are less likely to be controlled by standard phytosanitary treatments such as insecticides. Presumably the WFT 'lupin' strain was an early introduction into New Zealand from the west coast of North America. However, the origins of the WFT 'glasshouse' strain and IFT species in New Zealand are less obvious. Both were recorded in New Zealand before Australia, making Australia an unlikely source. The movement of horticultural produce, such as that reported by Stufkens \& Teulon (2003) in relation to the spread of the lettuce aphid, is likely to be a significant mechanism for the spread of flower thrips within New Zealand.

\section{ACKNOWLEDGEMENTS}

We thank all the growers who took part in this survey. Special thanks to Alex Smith (Horticultural Advisory Service Ltd), Terril Marais (Zonda) and Karyn Froud (MAF) for grower contacts. Anna Tier supplied us with data from the Plant Pest Information Network (PPIN) Database, Ministry of Agriculture and Forestry, New Zealand. We also acknowledge the assistance of Nicholas Martin and Marlon Stufkens, Crop \& Food Research. This research was funded by the New Zealand Foundation for Research, Science and Technology.

\section{REFERENCES}

Crosby TK, Dugdale JS, Watt JC 1976. Recording specimen localities in New Zealand: an arbitrary system of areas and codes defined. New Zealand Journal of Zoology 3: $69+$ map.

Gill G 2002. Action on new plant pests. Biosecurity 36. Ministry for Agriculture and Forestry publication. Biosecurity New Zealand, Wellington. p 14.

Kirk WDJ, Terry LI 2003. The spread of the western flower thrips Frankliniella occidentalis (Pergande). Agricultural and Forest Entomology 5: 301-310.

Lewis T 1997. Thrips as crop pests. CAB International, Wallingford, UK.

Martin NA, Workman PJ 1994. Confirmation of pesticide-resistant strain of western flower thrips in New Zealand. Proceedings of the 47th New Zealand Plant Protection Conference: 144-148.

Mound LA, Walker AK 1982. Terebrantia (Insecta: Thysanoptera). Fauna of New Zealand 1. Science Information Publishing Centre, Wellington. Pp. 1-113.

Mound LA, Walker AK 1986. Tubulifera (Insecta: Thysanoptera). Fauna of New Zealand 10. Science Information Publishing Centre, Wellington. Pp. 1-140.

Palmer JM, Mound LA, du Heaume GJ 1987. CIE guides to insects of importance to man. 2. Thysanoptera. CAB International Institute of Entomology, London, UK.

Stufkens MAW, Teulon DAJ 2003. Distribution, host range and flight pattern of the lettuce aphid in New Zealand. New Zealand Plant Protection 56: 27-32. 
Teulon DAJ, Penman DR 1995. Thrips obscuratus (Crawford) (Thysanoptera: Thripidae): A pest of stonefruit in New Zealand. In: Parker BL, Skinner M, Lewis T ed. Thrips Biology and Management, NATO ASI Series, Series A, Life Sciences, vol. 276. Plenum Press, New York. Pp. 101-104.

TABLE 1: Thrips species found in surveys of mostly indoor capsicum crops from the North and the South Islands of New Zealand. WFT=Western flower thrips, IFT=Intonsa flower thrips, NZFT=New Zealand flower thrips and $\mathrm{OT}=$ onion thrips. Note: All thrips were adults so that some thrips/host plant associations are likely to be incidental.

\begin{tabular}{|c|c|c|c|c|c|c|c|}
\hline $\begin{array}{l}\text { Crosby } \\
\text { code }\end{array}$ & Locality & Crop & WFT & IFT & NZFT & OT & $\begin{array}{l}\begin{array}{l}\text { Other } \\
\text { thrips }\end{array} \\
\end{array}$ \\
\hline \multicolumn{8}{|c|}{ North Island } \\
\hline ND & Whangarei & Capsicum & & & $1 ㅇ$ & $6 ㅇ ㅜ$ & \\
\hline $\mathrm{AK}$ & Warkworth & Capsicum & $55 \bigcirc 2 \sigma^{7}$ & & & & \\
\hline $\mathrm{AK}$ & Drury & Capsicum & 729 & qo $0^{12}$ & $+O^{12}$ & $\mathrm{Q}^{2}$ & \\
\hline WO & Ngatea & Capsicum & $3492 \sigma^{7}$ & 6690 260 & & $\begin{array}{l}+ \\
19\end{array}$ & \\
\hline WO & Hamilton & Capsicum & & 50 & $4 ㅇ$ & 50 & \\
\hline $\mathrm{BP}$ & Whakatane & Capsicum & & & & 2 우 & \\
\hline $\mathrm{BP}$ & Rotorua & Roses (outdoor) & & & 18 9 $9 \sigma^{7}$ & & \\
\hline GB & Gisborne & Calla lilies & & & $170_{1}^{+} 110^{7}$ & $2 q$ & 4 Q $C . f r i$ \\
\hline GB & Gisborne & Rose & & & 1 우 & 22 우 & \\
\hline TK & $\begin{array}{l}\text { New } \\
\text { Plymouth }\end{array}$ & Capsicum & $14+10^{x}$ & & & 19 & \\
\hline $\mathrm{HB}$ & Hastings & Capsicum & 1 우 & & & $6 ㅇ ㅜ$ & \\
\hline $\mathrm{HB}$ & Clive & Flowers & $5603 \sigma^{7}$ & & & 10 & \\
\hline WI & $\begin{array}{l}\text { Palmerston } \\
\text { Nth }\end{array}$ & Flowers & & & $6 ㅇ ㅜ$ & $11 q$ & \\
\hline WI & $\begin{array}{l}\text { Palmerston } \\
\text { Nth }\end{array}$ & Capsicum (outdoor) & & & & & \\
\hline WN & $\begin{array}{l}\text { Manakau- } \\
\text { Otaki }\end{array}$ & Flowers & 73 우 $20^{7}$ & & 7 우 $20^{7}$ & & \\
\hline WN & Otaki & Capsicum (outdoor) & & & 5 우 $30^{7}$ & 4 안. & \\
\hline \multicolumn{8}{|c|}{ South Island } \\
\hline $\mathrm{NN}$ & Richmond & Capsicum & & & & $7 ㅇ$ & \\
\hline $\mathrm{NN}$ & Richmond & Capsicum (outdoor) & 20 & & $4 ㅇ$ & 16 우 & \\
\hline $\mathrm{NN}$ & Richmond & Statice & $25 \% 10^{7}$ & & & $4 q$ & \\
\hline $\mathrm{NN}$ & Richmond & Chrysanthemum & $32+$ & & & 30 & \\
\hline $\mathrm{NN}$ & Westport & Capsicum & 40 & & $3 ㅇ$ & & \\
\hline MB & Blenheim & Capsicum & 1 우 & & & 1 우 & 1 Tub \\
\hline MB & Renwick & Gerbera & 4 우 & & $1 ㅇ$ & 10 & \\
\hline MB & Renwick & Mixed flowers & $53 q 10^{7}$ & & 7 우 & 17 웅 & $\begin{array}{l}2 q \text { P.ach } \\
1 \text { 으 C.fri }\end{array}$ \\
\hline $\mathrm{KA}$ & Kaikoura & Capsicum and chili & & & & 18 우 & \\
\hline KA & Kaikoura & Lettuce (indoor) & $1 \sigma^{7}$ & & & 19 & 19 L.cer \\
\hline $\mathrm{NC}$ & Rangiora & Chili pepper & 7 우 $10^{7}$ & & & 19 & \\
\hline $\mathrm{NC}$ & Waikuku $^{3}$ & Capsicum & $7 q$ & & & 8 8 & \\
\hline MC & Christchurch & Capsicum & $11+30^{7}$ & & & $5 q$ & \\
\hline $\mathrm{SC}$ & Timaru & Roses (outdoor) & 19 & & $24 q 24 \sigma^{r}$ & 19 & \\
\hline $\mathrm{SC}$ & Timaru & Capsicum & & & & 12 우 & \\
\hline MK & Twizel & Rose (outdoor) & 1 우 & & $48 q 50^{7}$ & & \\
\hline
\end{tabular}


TABLE 1: Ctd...

\begin{tabular}{|c|c|c|c|c|c|c|c|}
\hline $\begin{array}{l}\text { Crosby } \\
\text { code }\end{array}$ & Locality & Crop & WFT & IFT & NZFT & OT & $\begin{array}{l}\text { Other } \\
\text { thrips }^{1}\end{array}$ \\
\hline $\mathrm{OL}$ & Wanaka & Chili pepper & $24+120^{7}$ & & & & \\
\hline $\mathrm{CO}$ & Alexandra & Capsicum & $31 \nsubseteq 10^{7}$ & & & & \\
\hline DN & Mosgiel & Lily (indoor) & $48 \bigcirc 10^{7}$ & & $10^{7}$ & & \\
\hline DN & Oamaru & Cucumber & & & & $2 q$ & \\
\hline SL & Gore & Cucumber & & & 19 & $12 q$ & 5 우 A.sec \\
\hline SL & Gore & Cucumber & & & 10 & 27 우 & $\begin{array}{l}19 \text { ㅇ A.apt } \\
1 \text { \& A.fac }\end{array}$ \\
\hline SL & Edendale & $\begin{array}{l}\text { Capsicum \& mixed } \\
\text { flowers (indoor) }\end{array}$ & $213 q$ & & & & \\
\hline SI & $\begin{array}{l}\text { Half Moon } \\
\text { Bay }\end{array}$ & $\begin{array}{l}\text { Lettuce and tomato } \\
\text { (indoor) }\end{array}$ & & & & & none $^{4}$ \\
\hline
\end{tabular}

${ }_{1}^{1}$ A.fac=Aeolothrips faciatus, A.apt=Apterothrips apteris, C.fri=Ceratothrips frici, L.cer=Limothrips cerealium, P.ach=Pseudanaphothrips achaetus, Tub=Tubulifera.

${ }^{2}$ WFT, IFT, NZFT and OT were sampled from this greenhouse in water traps in April 2002.

${ }^{3}$ Sample taken in March 2005.

${ }^{4}$ No thrips in sample. 